\title{
In Vitro Regeneration and Mass Propagation of Ruta graveolens L.-A Multipurpose Shrub
}

\author{
Mohd Faisal, Naseem Ahmad, and Mohammad Anis ${ }^{1}$ \\ Plant Tissue Culture Laboratory, Department of Botany, Aligarh Muslim \\ University, Aligarh-202 002, India
}

Additional index words. nodal explants, plant growth regulators, shoot multiplication, tissue culture

\begin{abstract}
A protocol for rapid in vitro propagation of Ruta graveolens $\mathbf{L}$. through highfrequency shoot induction from nodal explants was established. Proliferation of shoots from nodal segments was achieved on Murashige and Skoog medium supplemented with various concentrations of $\mathrm{BA}$, Kin, IAA, and NAA, either singly or in various combinations. The highest shoot regeneration frequency $(98.5 \%)$ and the highest number of shoots per explant $(40.2 \pm 2.8)$ was obtained on MS medium supplemented with $10 \mu \mathrm{M}$ BA and 2.5 $\mu M$ NAA. In vitro regenerated shoots rooted best on half-strength MS medium containing $0.5 \mu$ IBA. Rooted shoots, following acclimatization in the greenhouse, were successfully transferred to field conditions, and $90 \%$ of plants survived. The efficient in vitro regeneration of the whole plant can be used as a fast and reliable method to transform $R$. graveolens genetically for its active principles.
\end{abstract}

Ruta graveolens (Rutaceae) is an ornamental, aromatic, culinary, and medicinal plant native to Europe, especially the Mediterranean region(CSIR, 1972). It is a very popular garden shrub in South America, where it is cultivated not only for ornamental and medicinal purpose but also as a charm against evil. Its medicinal values are because of the many secondary metabolites it contains, such as furocoumarins, furoquinolines, and acridone alkaloids. Amongst furocoumarins, bergapten has been used for the treatment of various skin diseases such as vitilago and psoriasis (Song and Tapley, 1979). All the parts of the plant material have active principles, although they are mostly encountered in leaves (especially before blooming). A pale yellow or greenish volatile oil, rue oil, often with a fluorescence, is obtained $(0.06 \%)$ on steam distillation of the fresh plant materials. Rue oil has a strong odor and a bitter pungent taste and is used as an anthelmintic, antispasmodic, antiepileptic, and rubefacient and as a flavoring agent in the perfume and soap industry. The soap is recommended for control of ectoparasite insects (lice). Rue oil consists predominantly of methyl-nonyl-ketone $(80 \%$ to $90 \%$ ) with a small amount of methyl-haptylketone. Methyl-nonyl-ketone induces uterine contractions and pelvic congestion, leading to uterine haemorrage and possibly abortion in pregnancy (Jougard, 1977).

Recently, there has been an increased interest in in vitro culture techniques that offer a viable tool for mass multiplication and germplasm preservation of aromatic and medicinal

Received for publication 2 Feb. 2005. Accepted for publication 1 Mar. 2005. The authors thank A K. Sharma, Deputy Director and Head, Tissue Culture Laboratory, National Botanical Research Institute (CSIR), Lucknow for helpful discussion and comments.

${ }^{1}$ To whom reprint requests should be addressed; e-mailanism1@rediffmail.com. plants (Amo-Macro and Ibanez, 1998; Arora and Bhojwani, 1989; Faisal and Anis, 2003; Pattnaik and Chand, 1996; Sudha and Seeni, 1994). Tissue cultures on $R$. graveolens were performed to monitor the alkaloid synthesis in callus cultures and regenerated plants (Baumert et al., 1991; Eilert and Wolters, 1989; Massot et al., 2000). In vitro cultures of $R$. graveolens are a potential source of secondary metabolites (furocoumarins) of significant medical interest. Massot et al. (2000) reported that micropropagated shoots were richer in furocoumarins than any other plant material. Because of the difficulty in producing seedlings to meet the demand, it is necessary to develop an in vitro protocol for its mass propagation. We describe an efficient protocol for rapid clonal multiplication of $R$. graveolens through highfrequency shoot induction from nodal explants followed by successful outdoor establishment of regenerated plants.

\section{Materials and Methods}

Plant material and explant preparation. Young shoots of $R$. graveolens were collected from 1-year-old plants maintained at the Botanical garden of the Aligarh Muslim University, Aligarh, India. The source tissues were washed in running tap water followed by treatment with a solution of $5 \%(\mathrm{v} / \mathrm{v})$ Labolene (Qualigens, India) for $5 \mathrm{~min}$. After thorough washing, they were surface sterilized using $0.1 \%(\mathrm{w} / \mathrm{v}) \mathrm{HgCl}_{2}$ (Qualigens, India) solution for $5 \mathrm{~min}$. Following repeated washes with sterile distilled water, nodal segments of 0.5 to $1 \mathrm{~cm}$ in length were cut and cultured on sterile media.

Media and culture conditions. Murashige and Skoog (1962) medium containing 3\%(w/v) sucrose (Qualigens, India) was used in all the experiments. The $\mathrm{pH}$ of medium was adjusted to 5.8 before the addition of $0.8 \%(\mathrm{w} / \mathrm{v})$ agar
(Qualigens, India). The media were sterilized by autoclaving at $1.06 \mathrm{~kg} \cdot \mathrm{cm}^{-2}$ for $20 \mathrm{~min}$. All the cultures were maintained at $24 \pm 2{ }^{\circ} \mathrm{C}$ under a 16-h photoperiod with a photosynthetic photon flux (PPF) density of $50 \mu \mathrm{mol} \cdot \mathrm{m}^{-2} \cdot \mathrm{s}^{-1}$ provided by cool white fluorescent lamps (Philips, India).

Shoot induction and multiplication. MS basal medium supplemented with 0.5 to $20 \mu \mathrm{M}$ 6-benzyladenine(BA), or 0.5 to $20 \mu \mathrm{M}$ kinetin, either individually or in combination with 0.5 to $5 \mu \mathrm{M}$ indole- 3 -acetic acid (IAA) or 0.5 to $5 \mu \mathrm{M} \alpha$-naphthalene acetic acid (NAA) were used for shoot proliferation and multiplication (Table 1). MS medium lacking plant growth regulators was used as control. All the cultures were subcultured to fresh medium of the same composition every 3 weeks.

Rooting and acclimatization. Regenerated shoots were excised when they reached about 4 to $5 \mathrm{~cm}$ in length and transferred onto halfstrength MS media supplemented with 0.5 to $2 \mu \mathrm{M}$ of IAA, indole-3-butyric acid (IBA), or NAA (Table 2). After 4 weeks, plantlets were removed from the root induction medium, washed with tap water to remove the remnants of culture medium and transplanted into pots containing sterile vermiculite and covered with transparent polyethylene bags to ensure high humidity. Polythene bags were removed after 2 weeks to acclimatize plants to field condition. The surviving plants were transplanted to the field condition after 2 months.

Data analysis. All the experiments were repeated three time and 20 replications were used for each treatment. The effect of different treatments was quantified and the data was analyzed using SPSS Version 10 (SPSS Inc. Chicago, Ill.) and means were compared using the Duncan's multiple range test at $P \leq 0.05$.

\section{Results and Discussion}

The present investigation was carried out to examine the morphogenic potential of nodal explants of the multipurpose shrub $R$. graveolens. Shoot regeneration from in vitro cultured nodal segments was tested on MS medium supplemented with various plant growth regulators either singly or in different combinations. Shoot bud proliferation was not induced from nodal explants cultured on MS medium without plant growth regulators. Multiple shoot sprouting appeared within 4 weeks of culture initiation and increased by subsequent subculturing during the second month. Significant differences in frequency of shoot regeneration and number of shoots per explant were detected among different concentration of $\mathrm{BA}$ and kinetin alone $(P \leq$ $0.05)$. A significant interaction between $\mathrm{BA}$ with IAA or NAA for shoot regeneration frequency and number of shoots per explants was also detected $(P \leq 0.05)$.

Nodal explants cultured on MS medium supplemented with various concentration of BA and Kin alone facilitated shoot bud initiation, with BA being more efficient than kinetin with respect to the initiation and subsequent proliferation of shoots (Table 1). Medium supplemented with $0.5 \mu \mathrm{M}$ BA induced a mean 

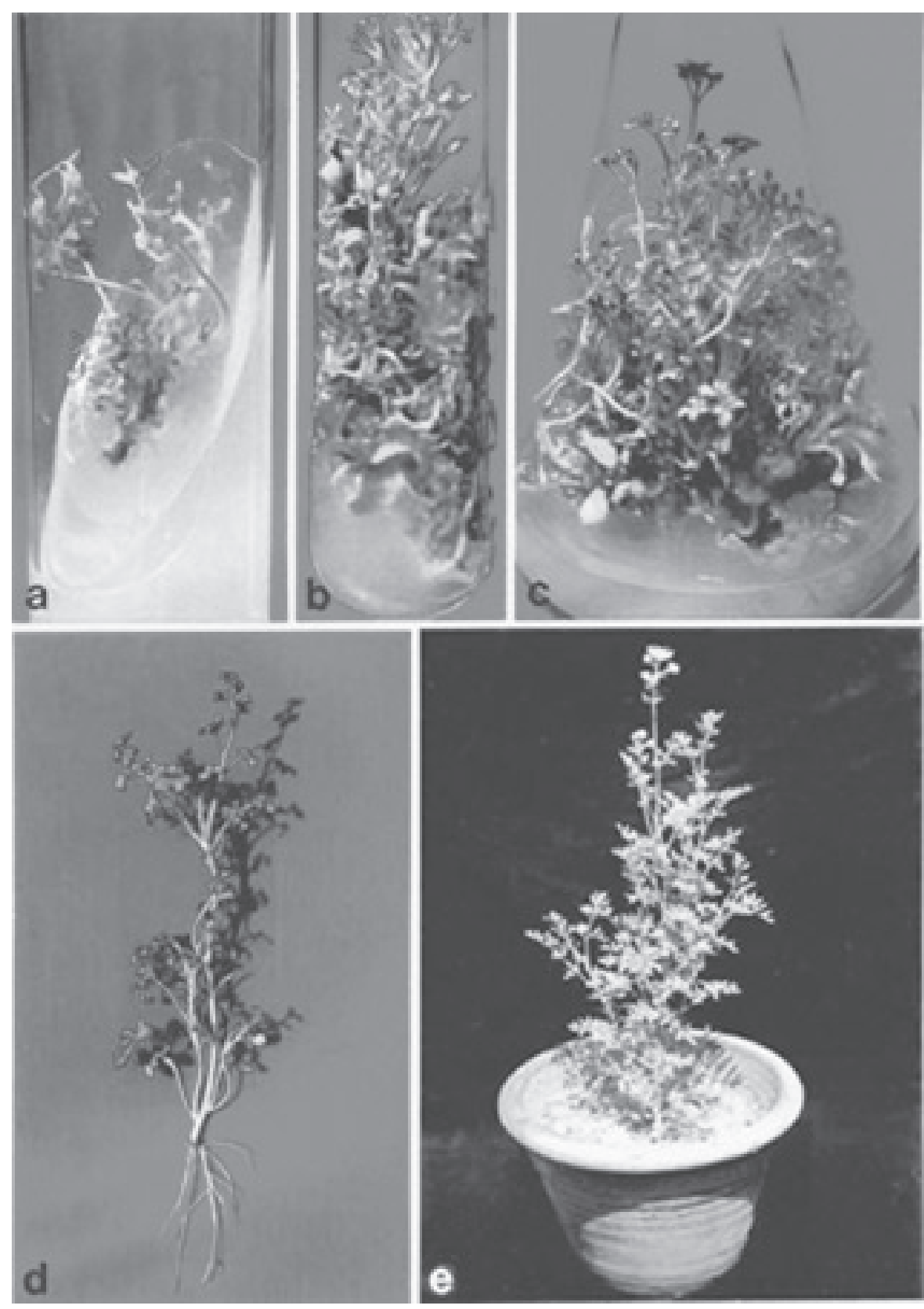

Table 1. Effect of plant growth regulators on shoot regeneration from nodal explants of Ruta graveolens after 8 weeks of culture.

\begin{tabular}{|c|c|c|c|c|c|}
\hline \multicolumn{4}{|c|}{ Growth regulator $(\mu \mathrm{M})$} & \multirow{2}{*}{$\begin{array}{c}\text { Regeneration } \\
(\%)\end{array}$} & \multirow{2}{*}{$\begin{array}{l}\text { Mean no. of } \\
\text { shoots/explant }\end{array}$} \\
\hline$\overline{\mathrm{BA}}$ & Kin & IAA & $\overline{\mathrm{NAA}}$ & & \\
\hline 0.0 & 0.0 & 0.0 & 0.0 & $0.0 \mathrm{j}^{\mathrm{z}}$ & 0.01 \\
\hline 0.5 & & & & $43.3 \pm 3.3 \mathrm{~g}$ & $4.0 \pm 0.9 \mathrm{jk}$ \\
\hline 2.5 & & & & $51.2 \pm 1.5 \mathrm{f}$ & $10.8 \pm 1.1 \mathrm{i}$ \\
\hline 5.0 & & & & $63.2 \pm 2.3 \mathrm{e}$ & $15.5 \pm 0.6 \mathrm{~h}$ \\
\hline 10 & & & & $83.8 \pm 3.7 \mathrm{c}$ & $22.5 \pm 1.0 \mathrm{f}$ \\
\hline 20 & & & & $80.5 \pm 2.5 \mathrm{c}$ & $15.7 \pm 0.9 \mathrm{~h}$ \\
\hline & 0.5 & & & $22.0 \pm 1.2 \mathrm{i}$ & $1.8 \pm 0.5 \mathrm{kl}$ \\
\hline & 2.5 & & & $32.8 \pm 1.3 \mathrm{~h}$ & $4.7 \pm 0.8 \mathrm{j}$ \\
\hline & 5.0 & & & $53.0 \pm 1.5 \mathrm{f}$ & $13.5 \pm 1.6 \mathrm{~h}$ \\
\hline & 10 & & & $70.5 \pm 2.6 \mathrm{~d}$ & $19.0 \pm 1.9 \mathrm{~g}$ \\
\hline & 20 & & & $61.5 \pm 1.9 \mathrm{e}$ & $13.3 \pm 0.6 \mathrm{~h}$ \\
\hline 10 & & 0.5 & & $71.3 \pm 2.5 \mathrm{~d}$ & $25.5 \pm 1.0 \mathrm{de}$ \\
\hline 10 & & 2.5 & & $90.0 \pm 3.1 \mathrm{~b}$ & $35.3 \pm 1.1 \mathrm{~b}$ \\
\hline 10 & & 5.0 & & $79.7 \pm 2.8 \mathrm{c}$ & $23.2 \pm 1.8 \mathrm{ef}$ \\
\hline 10 & & & 0.5 & $80.3 \pm 2.7 \mathrm{c}$ & $30.7 \pm 1.2 \mathrm{c}$ \\
\hline 10 & & & 2.5 & $98.5 \pm 4.1 \mathrm{a}$ & $40.2 \pm 2.8 \mathrm{a}$ \\
\hline 10 & & & 5.0 & $83.2 \pm 3.2 \mathrm{c}$ & $27.0 \pm 1.9 \mathrm{~d}$ \\
\hline
\end{tabular}

${ }^{2}$ Values represent the means \pm standard error of 20 explants per treatment in three repeated experiments Means followed by the same letter within columns are not significantly different $(P \leq 0.05)$ using Duncan's multiple range test.
Fig. 1. Plant regeneration from in vitro cultured nodal segments of Ruta graveolens L. (a) Proliferation of shoots on MS + BA $(0.5 \mu \mathrm{M})$. (b) Multiple shoot formation on MS $+\mathrm{BA}(10 \mu \mathrm{M})$. (c) Shoot elongation and multiplication on MS + BA (10 $\mu \mathrm{M})+\mathrm{NAA}(2.5 \mu \mathrm{M})$. (d) Rooting of in vitro raised microshoots on $1 / 2 \mathrm{MS}+$ IBA $(0.5 \mu \mathrm{M})$. (e) Flowered plant of $R$. graveolens (6 months after transplantation).

of $4.0 \pm 0.9$ shoots per explants (Fig. 1a), while medium supplemented with kinetin resulted in a reduced number of shoots albeit with longer internodes. The frequency of regeneration and number of shoots per explant was found maximum at $10 \mu \mathrm{MBA}$ Big. 1b). The percentage budbreak and multiple shoot induction declined with increase in BA concentration beyond optimal level $(10 \mu \mathrm{M})$. BA above 10 $\mu \mathrm{M}$ suppressed the sprouting of shoot buds in nodal explants. Reduction in the number of shoots generated from each explant at BA concentration higher than optimal level was also reported for several plants (Sahoo and Chand, 1998; Sen and Sharma, 1991; Vincent et al., 1992).

The effect of auxin and cytokinin combination was also evaluated on multiple shoot induction from nodal segments (Table 1). BA with NAA was found more effective combination for multiple shoot regeneration. Among the various concentration of BA and NAA, the highest shoot regeneration frequency $(98.5 \%)$ and number of shoots $(40.2 \pm 2.8)$ per explants were recorded on MS medium supplemented with $10 \mu \mathrm{M}$ BA and $2.5 \mu \mathrm{M}$ NAA (Fig. 1c). A decrease in induction and multiplication of shoots was recorded when NAA was replaced with IAA. The synergistic effect of BA and an auxin as in the present study has also been demonstrated in some plants, for example Santolina canescens (Casado et al., 2002), Holestemma ada-kodien (Martin, 2002), Rotula aquatica (Martin, 2003), and Olea europaea (Santos at al., 2003). In accordance with these reports, the present study also exemplifies the positive modification of shoot induction efficacy by an auxin in combination with a cytokinin.

The regenerated shoots from nodal explants were excised and transferred to half-strength MS medium supplemented with 0.5 to $2 \mu \mathrm{M}$ IAA, IBA, or NAA. The presence of auxin at lower concentration in half-strength MS medium facilitated better rhizogenesis. Halfstrength MS medium fortified with IBA was found superior to IAA and NAA with respect to the induction of roots (Table 2). The maximum frequency of root formation $(91.3 \%)$ and number $(6.2 \pm 0.4)$ of roots was achieved in half-strength MS medium containing 0.5 $\mu \mathrm{M}$ IBA (Fig. 1d). The effectiveness of IBA in rooting has been reported in Tylophora indica (Faisal and Anis, 2003), Holestemma ada-kodien (Martin, 2002), and Olea europaea (Santos et al., 2003).

Hardening and acclimatization of all the in vitro raised plantlets was completely successful. The percentage survival of the plantlets after transfer to vermiculite was $80 \%$. About $90 \%$ of the plants transferred to garden soil survived and did not show any detectable varia- 
Table 2. Effect of auxins on root induction from in vitro raised microshoots of Ruta graveolens in halfstrength MS medium after 4 weeks of culture

\begin{tabular}{ccccc}
\hline \multicolumn{2}{c}{ Auxins $(\mu \mathrm{M})$} & Rooting \\
$(\%)$ & $0.0 \mathrm{f}^{2}$ & $\begin{array}{c}\text { Mean no. of } \\
\text { roots/shoot }\end{array}$ \\
\hline IAA & IBA & NAA & $90.1 \pm 3.2 \mathrm{a}$ & $0.0 \mathrm{~d}$ \\
0.0 & 0.0 & 0.0 & $71.5 \pm 2.6 \mathrm{c}$ & $3.6 \pm 0.2 \mathrm{~b}$ \\
0.5 & & & $50.0 \pm 2.9 \mathrm{e}$ & $3.1 \pm 0.1 \mathrm{bc}$ \\
1.0 & & & $91.3 \pm 4.1 \mathrm{a}$ & $1.5 \pm 0.2 \mathrm{~d}$ \\
& 0.5 & & $62.6 \pm 3.5 \mathrm{~b}$ & $6.2 \pm 0.4 \mathrm{a}$ \\
& 1.0 & & $80.3 \pm 2.9 \mathrm{~d}$ & $3.3 \pm 0.2 \mathrm{~b}$ \\
& 2.0 & 0.5 & $62.1 \pm 2.5 \mathrm{~d}$ & $1.7 \pm 0.4 \mathrm{~d}$ \\
& 1.0 & $50.6 \pm 2.1 \mathrm{e}$ & $1.5 \pm 0.2 \mathrm{bc}$ \\
& 2.0 & & $1.2 \pm 0.2 \mathrm{~d}$ \\
\hline
\end{tabular}

${ }^{2}$ Values represent the means \pm standard error of 20 explants per treatment in three repeated experiments. Means followed by the same letter within columns are not significantly different $(P \leq 0.05)$ using Duncan's multiple range test.

tion in morphology or growth characteristics when compared with their respective donor plants (Fig. 1e).

In conclusion, an efficient procedure for high frequency shoot regeneration from nodal segments of $R$. graveolens has been demonstrated. The present study opens the way to scale-up studies to enhance biomass growth and eventually furocoumarin production with nodal segment cultures. The regeneration system developed is expected to facilitate our efforts in producing genotypes of commercial exploitation and provides the first step toward the genetic transformation studies aimed at improving the plant.

\section{Literature Cited}

Amo-Macro, J.B. and M.R. Ibanez. 1998. Micropropagation of Lilium cavanillesii Erben, a threatened statice, from inflorescence stems. Plant Growth Regulat. 24:59-54.

Arora, R. and S.S. Bhojwani. 1989. In vitro propagation and low temperature storage of Saussurea lappa C.B. Clarke-An endangered medicinal plant. Plant Cell Rpt. 8:44-47.

Baumert, A.D., B. Maier, W. Schuman, and D. Groger. 1991. Increased accumulation of acridone alkaloids by cell suspension cultures of Ruta graveolens in response to elicitors. J. Plant

Casado, J.P., M.C. Navarro, M.P. Utrilla, A. Martinez, and J. Jimenez. 2002. Micropropagation of Santolina canescens Lagasca and in vitro volatiles production by shoot explants. Plant Cell Tiss. Org. Cult. 69:147-153.

CSIR. 1972. The wealth of India, raw materials, p. 94-96. vol. IX. Publication and Information Directorate, CSIR, New Delhi, India.

Eilert, U. and B. Wolters. 1989. Elicitor induction of S-adenosyl- L-methionine: Anthranilic acid $\mathrm{N}$-methyltransferase activity in cell suspension and organ cultures of Ruta graveolens L. Plant Cell Tiss. Org. Cult. 18:1-18.

Faisal, M. and M. Anis. 2003. Rapid mass propagation of Tylophora indica via leaf callus culture. Plant Cell Tiss. Org. Cult. 75:125-129.

Jougard, J. 1977. Intoxication d'origine vegetale, Encyclopedie Medico Chirurgicale 16065:A10. Physiol. 139:224-228.
Martin, K.P. 2002. Rapid propagation of Holostemma ada-kodien Schult., a rare medicinal plant, through axillary bud multiplication and indirect organogenesis. Plant Cell Rpt. 21:112-117.

Martin, K.P. 2003. Rapid in vitro multiplication and ex vitro rooting of Rotula aquatica Lour., a rare rhoeophytic woody medicinal plant. Plant Cell Rpt. 21:415-420.

Massot, B., S. Milesi, E. Gontier, F. Bourgaud, and A. Guckert. 2000. Optimized culture conditions for the production of furancoumarins by micropropagated shoots of Ruta graveolens. Plant Cell Tiss. Org. Cult. 62:11-19.

Murashige, T. and F. Skoog. 1962. Arevised medium for rapid growth and bioassays with tobacco tissue cultures. Physiol. Plant. 15:473-497.

Pattnaik, S.K. and P.K. Chand. 1996. In vitro propagation of the medicinal herbs Ocimum americanum L. Syn., O. canum Slims (hoary basil) and Ocimum sanctum L. (holy basil). Plant Cell Rpt. 15:846-850.

Sahoo, Y. and P.K. Chand. 1998. Micropropagation of Vitex negundo L., a woody aromatic medicinal shrub, through high-frequency axillary shoot proliferation. Plant Cell Rpt. 18:301-307.

Santos, C.V., G. Brito, G. Pinto, M.A.C. Fonseca, and Henrique. 2003. In vitro plantlet regeneration of Olea europaea ssp. Maderensis. Scientia Hotr. 97:83-87.

Sen, J. and A.K. Sharma. 1991. Micropropagation of Withania somnifera from germinating seeds and shoot tips. Plant Cell Tiss. Org. Cult. 26:71-73.

Song,P.S. and K.J. Tapley. 1979. Photochemistry and photobiology of psoralens. Phtochem. Photobiol. 29:1177-1197.

Sudha, G.C. and S. Seeni. 1994. In vitro multiplication and field establishment of Adhatoda beddomei CB Clarke, a rare medicinal plant. Plant Cell Rpt. 13:203-207.

Vincent, K.A., K.M. Mathew, and M. Hariharan. 1992. Micropropagation of Kaempferiagalangal L.-A medicinal plant. Plant Cell Tiss. Org. Cult. 28:229-230. 